\title{
Další setkání a konfrontace s ruskou literaturou
}

\author{
Lenka Odehnalová (Brno)
}

Ivo Pospísil: Ruská literatura: setkání a konfrontace. Brno: Masarykova univerzita, 2020. 225 s. ISBN 978-80-210-9615-8.

V roce 2020 se objevila zajímavá publikace, jejíž autorem je brněnský rusista, slavista, literární vědec a překladatel, prof. PhDr. Ivo Pospísil, DrSc. Svazek s názvem Ruská literatura: setkání a konfrontace, jenž vznikl v rámci podpory výzkumu pracovišt Filozofické fakulty Masarykovy univerzity, volně navazuje na publikaci z roku 2008 Pátráni po nové identitěr zaměřenou rovněž na ruskou literaturu.

Většina studií je napsaná v ruském jazyce, najdeme však i několik česky psaných. Bližší pohled na publikaci přináší zjištění, že z tematického hlediska jsou v ní přítomny studie o slavistice, o jednotlivých spisovatelských osobnostech (N. M. Karamzin, A. S. Gribojedov, N. S. Leskov, F. M. Dostojevskij, M. Gorkij aj.), o ruské emigraci (A. L. Bem, V. Vilinskij), české recepci tvorby ruských spisovatelů (V. Rasputin, J. Vodolazkin) nebo studie zaměřeny na problematiku literárněvědné terminologie a samozřejmě literárních žánrů. Společným jmenovatelem všech studií je komparativní přistup se zaměřením na osobnosti nebo jevy, jež se bohužel stále nacházejí na periferii zájmu jak českých, tak i ruských literárních vědců.

Svazek uvádí studie věnovaná srovnání kořenů mezinárodní literárněvědné slavistiky v souvislosti s koncepčním vymezení ruské literatury (П. Й. Шафарик, А. Мичкевич и кониепиия русской литературы). Dílo slovenského filologa Pavla Jozefa Šafárika/Šafaříka, jenž svá díla psal v českém a německém jazyce, a polského básníka běloruského původu Adama Mickiewicze je zkoumáno v širším kontextu, konkrétně ve vzta-

1 POSPÍŠIL, Ivo: Pátráni po nové identitě. Rusistické a vztahové reflexe. Brno: SvN Regiony, Středoevropské centrum slovanských studií, 2008. 273 s. hu k tvorbě českých slavistů Jiřího Horáka, Jana Máchala a Franka Wollmana.

Ze studií zabývajících se problematikou spisovatelských osobností zaujme studie (Пеpeшагнуть порог эпох. Николай М. Карамзин и его позичия начинателя), v níž Ivo Pospíšil přiblížil osobnost a specifika tvorby Nikolaje Michajloviče Karamzina, jenž využíval poetologické impulzy různých uměleckých směrů, kromě sentimentalismu a preromantismu i baroka a klasicismu. Znalce i milovníky Dostojevského tvorby potěší studie Федор Михайловии Достоевский - проклатые вопросы его наследия zaměřena na tzv. prokleté otázky, tedy otázky existenciálního charakteru, také novátorství spisovatelovy tvorby a působení na světovou i českou literaturu.

Ve studii o ruskému spisovateli Maximu Gorkému (Maxim Gorkij: vynořováni epoch z hlubin zapomněni) autor publikace vymezuje místo Maxima Gorkého v ruské literatuře i v jeho české recepci. Definuje aspekty recepce Gorkého v českém prostředí, poukazuje na důležitost zkoumání spisovatelovy tvorby s odstupem a nadhledem, tedy její očištění od sovětských deformací. Ve vztahu k české recepci Gorkého tvorby je akcentována významnost díla brněnského badatele Jaroslava Buriana (1922-1980), jemuž je věnována také studie Ярослав Буриан (15 сентября 1922 Брно - 7 июля 1980 Париж) чешский русист на грани эпох: неизбежность третьего пути. O české recepci ruské literatury druhé poloviny 20. století pojednávají studie zaměřené na tvorbu V. Rasputina a J. Vodolazkina. Lze doplnit, že studie o prvním ze jmenovaných spisovatelů a jednom ze stěžejních představitelů tzv. vesnické prózy je dedikována překladateli ruské a jiných literatur SSSR Kamilu Chrobákovi. 
Důležité místo ve svazku zaujímají studie s tematikou ruské emigrace. Studie Ruský emigrant se dívá na meziválečné Československo a česko-slovenský vztah sleduje osobnost dalšího představitele ruské emigrace, a to syna smluvního profesora Masarykovy univerzity Sergije Vilinského, Valerije (1903-1955), jehož význam zastiňuje spolupráce se státní bezpečností. Osobnost Valerije Vilinského opět pozorujeme v širším kontextu, např́íklad také jako autora studií o české katolické literatuře (O. Březina, J. Durych, J. Deml), které publikoval v Polsku v polském jazyce. Ivo Pospíšil se zaměřuje na jeho text o ruské emigraci Rus se dívá na Č.S.R (1931), jenž podrobně analyzuje poměry v meziválečném Československu nejen zvenku, ale i zevnitř́; zabývá se národnostní otázkou, otázkou vztahů Čechů a Slováků a také idejemi čechoslovakismu. Text je dále srovnáván s publikací českého slavisty Josefa Jiráska Slovensko na rozcesti (1947).

Dopisy ruského emigranta a znalce Dostojevského tvorby Alfreda Ljudvigoviče Bema (18861945?) o ruské literatuře jsou v další studii (Tři listy o sovětské literatuře: ruský fenomén a středni Evropa) uvedeny do širšího kontextu a interpretovány, jak autor uvádí, z hlediska jiné kulturní zkušenosti a z perspektivy dneška. Bemovy názory týkající se vzniku hodnotné literatury jsou dále srovnány s pohledem Aloise Augustina Vrzala, autora prvních dějin ruské literatury v českém prostředí a překladatele děl N. S. Leskova.

$\mathrm{Na}$ žánrový charakter tvorby jednoho z nejznámějších ruských emigrantů, Alexandra Solženicyna, se Ivo Pospíšil soustředí ve studii Жанровые поиски в произведениях Солженицына.
Zároveň poukazuje na to, že jeho tvorba byla v minulosti redukována pouze na dvě díla Jeden den Ivana Denisoviče nebo Matrjoninu chalupu, přičemž žánrové rozpětí (termín I. Pospíšila) spisovatelovy tvorby je mnohem větší. $V$ další studii o problematice literárních žánrů je autorova pozornost věnována tvorbě Nikolaje Semjonoviče Leskova (Лесков и теория романа). Dominantní poetologické rysy Leskovových románů, jimiž jsou naprríklad kronikový charakter, role skazu, juxtapoziční ráz, ambivalentnost nebo spojení s folklorem, se dle autora mohou stát inspirací pro teorii románu.

Soubor uzavírá studie o univerzálním charakteru ruské literatury (Универсальный характер русской литературы в стадиальном освещении в перипетиях XIX-XXI веков: несколько заметок), v níž autor zkoumá změny v české recepci a také posuny významu v recepci ruské literatury od konce 19. století, na což poukazuje i prostřednictvím publikace Martina C. Putny Obrazy z kulturnich dějin ruské religiozity. Součástí svazku je i obrazová příloha, jež obsahuje portréty ruských spisovatelů a českých literárních vědců.

Závěrem lze konstatovat, že soubor studií Ruská literatura: setkáni a konfrontace představuje svým charakterem výjimečnou publikaci, která reflektuje jevy, jež se dlouhodobě nacházejí na okraji zájmu badatelů a v oblasti literárněvědného výzkumu tak vyplňuje pomyslná bílá místa. Je výsledkem několikaleté pečlivé badatelské práce, a proto na základě všech výše uvedených skutečností nepochybně osloví odbornou veřejnost v tuzemsku i v zahraničí.

\section{PaedDr. Lenka Odehnalová, Ph.D.}

Centrum jazykového vzdělávání, Univerzita obrany v Brně

Šumavská 4, 60200 Brno, Česká republika

Pedagogická fakulta, Univerzita Hradec Králové

lenka.odehnalova@unob.cz / 440234@mail.muni.cz

Rokitanského 62, 50003 Hradec Králové

Toto dílo Ize užít v souladu s licenčními podmínkami Creative Commons BY-SA 4.0 International (https://creativecommons.org/licenses/by-sa/4.0/legalcode). Uvedené se nevztahuje na díla či prvky (např. obrazovou či fotografickou dokumentaci), které jsou v díle užity na základě smluvní licence nebo výjimky či omezení př́slušných práv. 